\title{
Pemenuhan Hak Normatif Buruh Harian Lepas Pada PT. Hanuraba Sawit Kencana
}

\author{
Layang Sardana ${ }^{1 *}$, Suryati $^{2}$ \\ ${ }^{1,2}$ FKIP, Universitas PGRI Palembang, Jln. Jend. A. Yani, Lrg. Gotong Royong Palembang \\ *Correspondence email: layangsardana@gmail.com; suryatilasnai@gmail.com
}

\begin{abstract}
Abstrak. Jenis penelitianini adalah penelitian hukum normatif yang bersifat deskriptif dan didukung oleh data lapangan. Adapun yang menjadi permasalahan dalam penelitian ini adalah: Apakah terjadi kesenjangan dalam pemenuhan hak normatif buruh harian lepas berdasarkan Undang-Undang Nomor 13 tahun 2003 Tentang Ketenagakerjaan dan Keputusan Menteri No. 100 Tahun 2004 Tentang Ketentuan Perjanjian Kerja Waktu Tertentu dengan praktiknya pada PT. Hanuraba Sawit Kencana. Berdasarkan hasil penelitian yang sudah dilakukan di PT. Hanuraba Sawit Kencana, dapat disimpulkan beberapa hal mengenai bentuk perjanjian kerja antara buruh harian lepas dengan PT. Hanuraba Sawit Kencana dan tanggung jawab PT. Hanuaraba Sawit Kencana terhadap pemenuhan hak normatif buruh harian lepas sudah dijalankan sesuai dengan Undang-Undang Nomor 13 Tahun 2003 Tentang Ketenagakerjaan dan Keputusan Menteri Nomor 100 Tahun 2004 Tentang Ketentuan Pelaksanaan Perjanjian Kerja Waktu Tertentu.
\end{abstract}

Kata Kunci: Hak Normatif; Buruh Harian Lepas

Abstract. Type of this research was normative legal research that were descriptive and supported by data as for the packaging in this study is: Is there a gap in the fulfillment of the normative rights of freelance workers under Law No. 13 of 2003 on Employment and Ministerial Decree No. 100 of 2004 on the Terms of Certain Time Employment Agreements with practice at PT. Hanuraba Sawit Kencana? Based on the results of research that has been done in PT. HanurabaSawitKencana, can be summed up some things about the form of labor agreement between freelance labors and PT. HanurabaSawitKencana and the responsibilities of PT. HanuarabaSawitKencana towards the fulfillment of normative rights of freelance labors has been carried out in accordance with Law No. 13 of 2003 on Employment and Ministerial Decision No. 100 of 2004 On The Tenaity of The Implementation of Certain Time Work Agreements.

Keywords: Normative Rights; Freelance Daily Labor

\section{PENDAHULUAN}

Melihat perjanjian kerja yang dibuat dengan sederhana, penulis akan mengkaji apakah terjadi kesenjangan dalam pemenuhan hak buruh harian lepas yang dilakukan PT. Hanuraba Sawit Kencana dalam memenuhi tanggung jawabnya terhadap pemenuhan hak normatif buruh harian lepas, penulisan ini berpedoman pada UU No. 13 Tahun 2003 Tentang Ketenagakerjaan dan KEPMEN No. 100 Tahun 2004 Tentang Ketentuan Pelaksanaan Perjanjian Kerja Waktu Tertentu.

Hak normatif merupakan semua yang dimiliki buruh yang tercantum dalam peraturan perundang-undangan ketenagakerjaan, perjanjian kerja, peraturan perusahaan dan/atau perjanjian kerja bersama. Hak normatif terdiri dari hak yang bersifat ekonomis, medis, politis dan sosial.

Hak buruh yang paling dasar memang mendapatkan upah, selain upah, buruh juga berhak memperoleh perlindungan selama bekerja, oleh karena itu perusahaan menyediakan alat perlindungan diri dan memberikan jamsostek atau sekarang dikenal dengan nama BPJS Ketenagakerjaan kepada buruh harian lepas.

Selain menerima hak, buruh juga terikat dengan kewajiban terhadap perusahaan, melaksanakan pekerjaan sebagai akibat dari upah yang diterima dan menggunakan alat perlindungan diri yang telah disediakan oleh perusahaan selama bekerja, selain itu buruh juga diwajibkan mengikuti peraturan perusahaan selama buruh bekerja di PT. Hanuraba Sawit Kencana.

Peraturan perusahaan tersebut antara lain jam masuk serta pulang kerja, perhitungan upah lembur, penggunaan alat APD (Alat Perlindungan Diri), dan lainnya. Buruh harian lepas mendapatkan hak yang sama dengan karyawan tetap diantaranya rumah berserta sarana dan prasarana, upah berdasarkan UMSP (Upah Minimum Sektor Perkebunan) perlindungan keselamatan dan kesehatan selama bekerja, namun status buruh harian lepas tidak sama dengan karyawan tetap.

Adapun yang menjadi permasalahan dalam penelitian ini adalah: apakah terjadi kesenjangan dalam pemenuhan hak normatif buruh harian lepas berdasarkan UU No. 13 tahun 2003 Tentang Ketenagakerjaan dan KEPMEN No. 100 Tahun 2004 Tentang Ketentuan Perjanjian Kerja Waktu Tertentu pada PT. Hanuraba Sawit Kencana? 


\section{METODE}

Jenis penelitian ini adalah penelitian Normatif yang bersifat deskriptif dan didukung oleh data lapangan dengan menggambarkan bentuk dari perjanjian kerja antara buruh harian lepas dengan PT. Hanuraba Sawit Kencana serta tanggung jawab PT. Hanuraba sawit kencana terhadap pemenuhan hak normatif buruh harian lepas dilihat dari UU No. 13 Tahun 2003 dan KEPMEN No. 100 Tahun 2004.

\section{HASIL DAN PEMBAHASAN}

Untuk mengetahui apakah terjadi kesenjangan dalam pemenuhan hak normatif buruh harian lepas berdasarkan UU No. 13 tahun 2003 Tentang Ketenagakerjaan dan KEPMEN No. 100 Tahun 2004 Tentang Ketentuan Perjanjian Kerja Waktu Tertentu dengan praktiknya pada PT. Hanuraba Sawit Kencana akan dideskripsikan dalam pemenuhan hak-hak berikut:

Tanggung jawab PT. Hanuraba Sawit Kencana terhadap pemenuhan hak normatif buruh harian lepas adalah:

\section{Hak yang bersifat ekonomis}

Kata "ekonomis" menurut KBBI (Kamus Besar Bahasa Indonesia) adalah "bersifat hati-hati dalam pengeluaraan uang, penggunaan barang, bahasa, waktu, tidak boros, hemat. Hak bersifat ekonomis di sini terkait dengan upah.”Undang-Undang No. 13 Tahun 2003 tentang Ketenagakerjaan pada pasal 1 angka 30 dikatakan bahwa: "Upah adalah hak pekerja/buruh yang diterima dan dinyatakan dalam bentuk uang sebagaimana imbalan dari pengusaha atau pemberi kerja kepada pekerja/buruh yang ditetapkan dan dibayarkan menurut suatu perjanjian kerja, kesepakatan, atau peraturan perundang-undangan, termasuk tunjangan bagi pekerja/buruh dan keluarganya atas suatu pekerjaan dan/atau jasa yang telah atau akan dilakukan"

Selanjutnya dalam pasal 88 UU No. 13 Tahun 2003 Tentang Ketenagakerjaan "Setiap pekerja/buruh berhak memperoleh penghasilan yang memenuhi penghidupan yang layak bagi kemanusiaan"."Kebijakan pengupahan yang melindungi pekerja meliputi:

1. Upah minimum;

2. Upah kerja lembur;

3. Upah tidak masuk kerja karena berhalangan;

4. Upah tidak masuk kerja karena melakukan kegiatan lain di luar pekerjaannya;

5. Upah karena menjalankan hak waktu istirahat kerjanya;

6. Bentuk dan cara pembayaran upah;

7. Denda dan potongan upah;

8. Hal-hal yang dapat diperhitungkan dengan upah;

9. Struktur dan skala pengupahan yang proporsional;

10.Upah untuk pembayaran pesangon; dan

11.Upah untuk perhitungan pajak penghasilan.”

Ketentuan mengenai upah minimum dalam pasal; 89 UU No. 13 Tahun 2003 Tentang Ketenagakerjaan dibagi menjadi:

1. Upah minimum berdasarkan wilayah provinsi atau kabupaten/kota,

2. Upah minimum berdasarkan sektur pada wilayah provinsi atau kabupaten kota.

Pasal 17 ayat (2) Permenakertrans No. 7 Tahun 2013 Tentang upah minumun yaitu: "upah pekerja/buruh harian lepas, ditetapkan secara bulanan yang dibayarkan berdasarkan jumlah hari kehadiran dengan perhitungan upah sehari:

1. Bagi perusahaan dengan sistem kerja 6 (enam) hari dalam seminggu, upah bulanan dibagi 25 (dua puluh lima)

2. Bagi perusahaan sistem kerja 5 (lima) hari dalam seminggu, upah bulanan dibagi 21 (dua puluh satu)"

"Upah yang diterima buruh harian lepas di PT. Hanuraba Sawit Kencana berdasarkan kehadiran, yaitu RP. 107.200-/ HKE (Sembilan puluh tujuh ribu dua ratus per hari kerja efektif). Upah dibayarkan secara bulanan."

Perusahaan juga wajib memberikan upah lembur sebagaimana yang disebutkan dalam Keputusan Menteri Kepmenkertranas No. Kep. 102/MEN/VI/2004 yang berisi: "Pengusaha yang mempekerjakan pekerja/buruh melebihi waktu kerja, wajib membayar upah lembur." Waktu Kerja lembur dan penghitungan upah lembur diatur dalam KEPMEN No. 102 Tahun 2004 Tentang Waktu Kerja Lembur Dan Upah Kerja Lembur.

Upah lembur yang diberikan oleh PT. Hanuraba Sawit Kencana dengan perhitungan sebagai berikut:

$1 \mathrm{jam}=1,5 \times 20.000=30.000$

$2 \mathrm{jam}=3,5 \times 20.000=70.000$

${ }^{1}$ Wawancara dengan Berkah Aditio Basri, selaku Asisstant Manager People \& Organization, pada tanggal 6 Desember 2019. 


\section{$3 \mathrm{jam}=5,5 \times 20.000=110.000$}

Dan akan terus meningkat perjamnya.

"Jam mulai bekerja adalah jam 7 pagi, istirahat siang dari jam 12 siang sampai jam 2 dilanjutkan bekerja lagi dari jam 2 siang sampai jam 4 sore. Rata-rata setelah jam kerja berakhir saya lembur 2 jam perharinya"

Pasal 94 UU No. 13 Tahun 2003 Tentang Ketenagakerjaan menyebutkan: "dalam hal komponen upah terdiri dari upah pokok dan tunjangan tetap maka bersarnya upah pokok sedikitnya 75\% (tujuh puluh lima perseratus) dari jumlah sedikitnya $75 \%$ (tujuh puluh lima perseratus) dari jumlah upah pokok dan tunjangan tetap."

Surat Edaran Menteri Tenaga Kerja Nomor: SE-07/MEN/1990 Tentang Pengelompokan Upah, komponen Upah terdiri dari:

1. "Upah atau gaji pokok

Upah pokok adalah imbalan dasar yang dibayarkan kepada pekerja menurut tingkat atau jenis pekerjaan yang besarnya ditetapkan berdasarkan kesepakatan.

2. Tunjangan Tetap

Tunjangan tetap adalah suatu pembayaran yang teratur berkaitan dengan pekerjaan yang diberikan secara tetap untuk pekerja dan keluarganya serta dibayarkan dalam satuan waktu yang sama, dengan pembayaran upah pokok, seperti Tunjangan Istri; Tunjangan Anak; Tunjangan Perumahan; Tunjangan Kemahalan; Tunjangan Daerah dan lain-lain. Tunjangan Makan dan Tunjangan Tranport dapat dimasukkan dalam komponen tunjangan tetap apabila pemberian tunjangan tersebut tidak dikaitkan dengan kehadiran, dan diterima secara tetap oleh pekerja menurut satuan waktu, harian atau bulanan.

3. Tunjangan Tidak Tetap

Tunjangan tidak tetap adalah suatu pembayaran secara langsung atau tidak langsung berkaitan dengan pekerja, yang diberikan secara tidak tetap untuk pekerja dan keluarganya serta dibayarkan menurut satuan waktu yang tidak sama dengan waktu pembayaran upah pokok, seperti Tunjangan Transport yang didasarkan pada kehadiran, Tunjangan Makan dapat dimasukkan ke dalam tunjangan tidak tetap apabila tunjangan tersebut diberikan atas dasar kehadiran (pemberian tunjangan biasa dalam bentuk uang atau fasilitas makan).

Komponen non upah diantaranya:

a. Fasilitas: adalah kenikmatan dalam bentuk nyata/nature yang diberikan perusahaan oleh karena hal-hal yang bersifat khusus atau untuk meningkatkan kesejahteraan pekerja, seperti fasilitas kendaraan (antar jemput pekerja atau lainnya); pemberian makan secara cuma-cuma; sarana ibadah; tempat penitipan bayi; koperasi; kantin dan lain-lain.

b. Bonus: adalah bukan merupakan bagian dari upah, melainkan pembayaran yang diterima pekerja dari hasil keuntungan perusahaan atau karena pekerja menghasilkan hasil kerja lebih besar dari target produksi yang normal atau karena peningkatan produktivitas; besarnya pembagian bonus diatur berdasarkan kesepakatan.

c. Tunjangan Hari Raya (THR) Gratifikasi dan pembagian keuntungan lainnya."

Berdasarkan wawancara dengan pihak HSSE Officer,tunjangan yang diberikan kepada buruh harian lepas sebagai berikut:

"PT. Hanuraba Sawit Kencana memberikan fasilitas berupa tempat tinggal (barak), beserta sarana dan prasarana di dalamnya, buruh harian lepas juga memperoleh jamsostek, dan tunjangan hari raya (THR) sebesar satu bulan gaji yang masuk dalam daftar tunjangan tetap perusahaan.

Untuk tunjangan tidak tetap PT. Hanuraba Sawit Kencana menyediakan transportasi yang bisa digunakan dalam keadaan darurat seperti keadaan akan melahirkan ataupun keadaan lain yang dapat dikategorikan dalam keadaan darurat." ${ }^{3}$ Bahwa sebahagian besar hak-hak normatif buruh yang bersifat ekonomis sudah dapat dipenuhi oleh PT. Hanuraba Sawit Kencana. Hal itu terlihat dari adanya Upah Pokok, tunjangan tetap dan tunjangan tidak tetap yang diberikan oleh PT. Hanuraba Sawit Kencana kepada buruh harian lepas.

\section{Hak bersifat politis}

Hak bersifat politis diantaranya dengan membentuk organisasi serikat buruh, bergabung atau tidak dengan organisasi serikat buruh.

Serikat Buruh di dalam PT. Hanuraba Sawit Kencana sudah terbentuk, organisasi serikat buruh bernama SPSI (Serikat Pekerja Seluruh Indonesia), yang diketuai oleh Bapak Roso. Untuk pelaksanaannya tidak berjalan sebagaimana harusnya atau bisa dikatakan serikat buruh di PT. Hanuraba sawit kencana vakum, hal ini disebabkan karena buruh harian lepas di PT. Hanuraba Sawit Kencana tidak memahami caranya berorganisasi serikat buruh dan bagaimana pelaksanaan-pelaksanaan kegiatan organisasi tersebut hal ini menyebabkan tidak adanya perwakilan antara

\footnotetext{
${ }^{2}$ Wawancara dengan Firman, buruh harian lepas PT. Hanuraba Sawit Kencaana pada tanggal 15 Desember 2019.

${ }^{3}$ Wawancara dengan Delta Pranico selaku HSSE Officer, pada tanggal 5 Desember 2019.
} 
buruh harian lepas dengan PT. Hanuraba Sawit Kencana saat terjadi masalah yang menyangkut hak-hak normatif buruh harian lepas. Jadi dalam hal ini, kendalanya bukan dari perusahaan, melainkan dari buruh sendiri yang belum mempunyai kader yang cakap dalam menjalankan organisasi tersebut.

\section{Hak bersifat medis}

Hak bersifat medis terdiri dari Hak atas keselamatan dan kesehatan kerja, hak melahirkan dan menyusui anak serta hak istirahat.

Dalam bentuk memenuhi tanggung jawab terhadap hak buruh yang bersifat medis, PT. Hanuraba Sawit Kencana menyediakan Poliklinik Kebun (POLIBUN) yang bisa digunakan tenaga kerja baik yang bersifat tetap maupun harian lepas. "POLIBUN memiliki tugas dan fungsi yaitu melayani kesehatan tenaga kerja di PT. Hanuraba Sawit Kencana, konsultasi kesehatan, imunisasi bayi, balita, dan pemeriksaan ibu hamil, melahirkan, KB, sunat, tindik, rawat jalan serta pengobatan.

Untuk tenaga kerja yang sakit atau lukanya dalam kondisi parah, maka akan dirujuk ke Palembang dan biaya pengobatannya ditanggung oleh perusahaan."

POLIBUN memiliki 3 (tiga) anggota, diantaranya 2 bidan, 1 perawat. POLIBUN memiliki jam kerja selama 7 jam dan tetap akan melayani diluar jam kerja dengan catatan dalam keadaan/posisi darurat.”

Selain POLIBUN perusahaan juga menyediakan dan mewajibkan pekerjanya menggunakan alat perlindungan diri (APD) demi keselamatan buruh saat bekerja.

Untuk kecelakaan kerja, pihak HSSE Officer yang bertanggung jawab pada keselamatan karyawan PT. Hanuraba Sawit Kencana pada saat wawancaranya mengatakan: "Kecelakaan kerja ada 3 kategori, kecelakaan saat bekerja, kecelakaan dalam perjalanan pergi bekerja, dan kecelakaan dalam perjalanan pulang bekerja"

Untuk kecelakaan kerja selama bekerja perusahaan bertanggung jawab sepenuhnya namun untuk kecelakaan saat dalam perjalanan pergi bekerja ataupun pulang bekerja, perusahaan melakukan penyelidikan.

"Kita lihat dulu niatnya, jika memang untuk bekerja, maka perusahaan akan memberikan tanggung jawabnya, jalur keperusahaan hanya ada satu jalur, dan jika terjadi kecelakaan namun tidak dalam jalur menuju perusahaan maka perusahaan tidak akan bertanggung jawab atas kecelakaan yang terjadi. Berlaku juga untuk kecelakaan yang terjadi setelah pulang bekerja, jika jalurnya untuk pulang ke rumah, perusahaan akan bertanggung jawab, namun jika dia berbelok kearah lain dalam hal ini bukan rumahnya, maka perusahaan tidak akan bertanggung jawab"5

Setiap pekerja/buruh dan keluarganya berhak untuk memperoleh jaminan sosial tenaga kerja, sebagaimana yang dimaksud dalam Pasal 99 Undang-Undang No. 13 tahun 2003 Tentang Ketenagakerjaan. Selain itu, pengusaha wajib untuk menyediakan fasilitas kesejahteraan untuk meningkatkan kesejahteraan bagi para pekerjanya."PT. Hanuraba Sawit Kencana mendaftarkan seluruh karyawannya baik yang bersifat tetap ataupun lepas ke badan pengelola jaminan sosial (BPJS) Ketenagakerjaan, selanjutnya untuk fasilitas PT. Hanuraba Sawit Kencana menyediakan:

1. Tempat tinggal berupa barak dan rumah yang meliputi air dan listrik, lokasi disesuaikan dengan devisi. Rumah terbagi menjadi dua jenis, yaitu G 2 dan G 10

G 2 ditempati oleh manager, asisten manager dan karyawan lain yang lokasinya dekat dengan devisinya. G 10 ditempati rata-rata oleh buruh harian lepas bagian perkebunan, workshop, transport dan lainnya Barak ditempati buruh harian bagian perkebunan

2. Sarana dan prasarana

Sarana berupa alat-alat bekerja, alat perlindungan diri saat bekerja, dan transportasi. Prasarana perusahaan menyediakan lapangan futsal, voli dan lainnya untuk karyawan berolahraga.

3. Poliklinik Kebun

4. Dan lainnya

Bentuk tanggung jawab lainnya PT. Hanuraba Sawit Kencana terhadap hak normatif berisfat medis buruh harian lepas adalah dengan diadakannya satu bulan sekali program imunisasi dan pemeriksaan ibu hamil di POLIBUN.

Dari uraian di atas dapat disimpulkan bahwa sebahagian besar hak-hak normatif buruh yang bersifat medis sudah dapat dipenuhi oleh PT. Hanuraba Sawit Kencana. Hal itu terlihat dari adanya Poliklinik Kebun (POLIBUN) yang bisa digunakan tenaga kerja baik yang bersifat tetap maupun harian lepas, termasuk konsultasi kesehatan, imunisasi bayi, balita, dan pemeriksaan ibu hamil, melahirkan, KB, sunat, tindik, rawat jalan serta pengobatan. Selain itu, untuk tenaga kerja yang sakit atau lukanya dalam kondisi parah, maka akan dirujuk ke Palembang dan biaya pengobatannya ditanggung oleh perusahaan."

\footnotetext{
${ }^{4}$ Wawancara dengan Neri Arisa, Selaku Bidan di POLIBUN PT. Hanuraba Sawit Kencana, pada tanggal 5 Desember 2019.

${ }^{5}$ Wawancara dengan Delta Pranico selaku HSSE (Health, Safety, Security, Environment) Officer, pada tanggal 5 Desember 


\section{Hak bersifat sosial}

Hak ini berkaitan dengan hak cuti, pembatasan pekerjaan anak dan perempuan pada malam hari, dan lainnya. Istirahat kerja di PT. Hanuraba Sawit Kencana adalah 2 (dua) hari untuk 5 (lima) hari kerja dalam 1 (satu) minggu yang diterapkan pada hari sabtu dan minggu.Kemudian untuk hak istirahat kerja, buruh harian lepas di PT. Hanuraba Sawit Kencana dibebaskan memilih jam istirahatnya, selama tetap dalam aturan jam kerja perusahaan yaitu 8 jam kerja, 1 jam istirahat atau 40 jam kerja dalam satu minggu.

Buruh harian lepas mengatakan dalam wawancara, "Jam masuk kerja kita mulainya jam 7 pagi, sampai jam 12 siang, kemudian lanjut kerja jam dua siang sampai jam 4 sore" 6

Saat jam istirahat banyak karyawan yang memilih pulang (istirahat di rumah) karena tempat tinggal mereka berada dekat dengan lokasi devisi mereka.

"PT. Hanuraba Sawit Kencana memberikan cuti melahirkan dan menyusui tetapi untuk karyawan tetap yaitu selama 3 bulan yang terbagi menjadi 1,5 bulan sebelum melahirkan dan 1,5 bulan setelah melahirkan dan perusahaan tetap memberikan gaji penuh pada karyawan yang cuti. Untuk karyawan laki-laki, perusahaan memberikan cuti 3 hari setelah istri karyawan bersangkutan melahirkan." "Tidak ada cuti untuk karyawan harian lepas di PT. Hanuraba Sawit Kencana, mereka bersifat lepas, tetapi dapat meminta izin kepada perusahaan jika berhalangan/tidak bisa masuk bekerja.

Cuti hamil, melahirkan, menyusui serta menemani istri saat melahirkan hanya dapat diterapkan pada karyawan bersifat tetap, karena karyawan harian lepas dipekerjakan kurang dari 21 hari, tetapi perusahaan memberikan izin bagi karyawan harian lepas untuk menemani istri melahirkan." Izin yang diberikan perusahaan tergantung dengan kebutuhan buruh, tetapi tidak lebih dari 3 hari, selama buruh izin tidak bekerja buruh tersebut tidak mendapatkan upahnya.

"Tidak ada jam kerja malam untuk wanita juga tidak ada pekerja anak dalam PT. Hanuraba Sawit Kencana." 9

Selanjutnya, prosedur pengangkatan karyawan tidak tetap menjadi karyawan tetap di PT. Hanuraba Sawit Kencana. Sesuai dengan UU No. 13 Tahun 2003 Tentang Ketenagakerjaan pasal 58 dan 59nya berbunyi:

(1) Perjanjian kerja untuk waktu tertentu tidak dapat mensyaratkan adanya masa percobaan kerja.

(2) Dalam hal disyaratkan masa percobaan kerja dalam perjanjian kerja sebagaimana dimaksud dalam ayat (1), masa percobaan kerja yang disyaratkan batal demi hukum.

Hasil dari wawancara dengan HSSE (Health, Safety, Security, Environment) Officer menjelaskan prosedur pengangkatan karyawan harian lepas menjadi karyawan harian tetap sebagai berikut:"Pengangkatan karyawan tidak tetap menjadi karyawan tetap didasarkan pada penilaian kerja. Selama 3 bulan sekali akan diadakan evaluasi, berlanjut ke 6 bulan bekerja dilakukan pemantauan dan jika dalam jangka setahun pekerja bekerja dengan baik (berprestasi) maka akan direkomendasikan berdasarkan kebutuhan.

Kemudian untuk fasilitas yang diberikan kepada tenaga kerja yang sudah diangkat menjadi karyawan tetap sama dengan buruh harian lepas, namun karyawan tetap diikutsertakan dalam program BPJS Ketenagakerjaan yang meliputi program jaminan hari tua (JHT), jaminan kematian (JKM) dan jaminan kecelakaan kerja (JKK) juga jaminan pensiun, serta BPJS Kesehatan." 10

Dengan ini dapat disimpulkan jika tanggung jawab PT. Hanuraba Sawit Kencana bersifat ekonomis dengan memberikan upah sebesar UMSP (Upah Minimun Sektor Perkebunan) yaitu sebesar RP. 97.200-/HKE (Sembilan puluh tujuh ribu dua ratus rupiah perhari kerja efektif yang dibayarkan perbulannya sebesar RP.4.86.000 - (empat juta depalan puluh enam ribu rupiah). Upah lembur perjamnya dibayarkan sebesar RP. 14.046 (empat belas ribu empat puluh enam rupiah) yang akan terus meningkat perbulannya, selain itu buruh harian lepas juga memperoleh fasilitas perumahan beserta sarana dan prasarana di dalamnya, tunjangan hari raya dan jaminan kesehatan.

Kemudian tanggung jawab PT. Hanuraba Sawit Kencana yang bersifat politis yaitu mengizinkan terbentuknya serikat buruh bernama SPSI (Serikat Pekerja Seluruh Indonesia) dan tidak melarang siapapun untuk bergabung, namun serikat tersebut vakum dikarenakan buruh di sana tidak mengenal bagaimana berorganisasi serikat bururh serta pelaksanaan kegiatan organisasi tersebut.

Selanjutnya tanggung jawab PT. Hanuraba Sawit Kencana yang bersifat medis adalah dengan menyediakan POLIBUN (Poli Klinik Kebun), yang memiliki tugas serta fungsi melayani kesehatan tenaga kerja di PT. Hanuraba Sawit Kencana, konsultasi kesehatan, melahirkan, KB, hingga sunat. Dalam hal kecelakaan kerja yang perlu rujukan

\footnotetext{
${ }^{6}$ Wawancara dengan Firman, buruh harian lepas di PT. Hanuraba Sawit Kencana, pada tanggal 15 Desember 2019

7 Wawancara dengan Joni M Yasin, selaku Senior Estate Manager di PT. Hanuaraba Sawit Kencana, pada tanggal 10 Desember 2019.

${ }^{8}$ Wawancara dengan Joni M Yasin, selaku Senior Estate Manager di PT. Hanuraba Sawit Kencana, pada tangal 10 Desember 2019.

${ }^{9}$ Wawancara dengan Delta Pranico, selaku HSSE Officer di PT. Hanuraba Sawit Kencana, pada tanggal 5 Desember 2019.

10 Wawancara dengan Delta Pranico, selaku HSSE Oficer di PT. Hanuraba Sawit Kencana, pada tanggal 5 Desember 2019.
} 
ke rumah sakit yang berada di Palembang, perusahaan menanggung penuh biaya pengobatan buruh harian lepas sampai buruh tersebut dinyatakan sehat (dapat keluar dari rumah sakit) oleh dokter.

Untuk tanggung jawab PT. Hanuraba Sawit Kencana yang bersifat sosial, perusahaan tidak memberikan cuti pada buruh harian lepas, tetapi hanya member izin tidak masuk kerja bagi karyawannya (baik pria maupun wanita) walaupun sudah ada peraturan yang melindungi hak tenaga kerja wanita yang melahirkan agar dapat cuti. Hal ini menyebabkan bagi buruh harian lepas yang tidak masuk kerja karena melahirkan tersebut tidak diberikan upah oleh perusahaan.

\section{SIMPULAN}

Berdasarkan hasil penelitian yang sudah dilakukan di PT. Hanuraba Sawit Kencana, dapat disimpulkan beberapa hal:

1. Mengenai bentuk perjanjian kerja antara buruh harian lepas dengan PT. Hanuraba Sawit Kencana dan tanggung jawab PT. Hanuraba Sawit Kencana terhadap pemenuhan hak normatif buruh harian lepas sudah dijalankan sesuai dengan Undang-Undang No. 13 Tahun 2003 Tentang Ketenagakerjaan dan KEPMEN No. 100 Tahun 2004 Tentang Ketentuan Pelaksanaan Perjanjian Kerja Waktu Tertentu.

2. Tanggung jawab PT. Hanuraba Sawit Kencana terhadap pemenuhan hak normatif buruh harian lepas yang bersifat ekonomis yaitu memberikan upah sebesar RP. 97.200-/HKE (Sembilan puluh tujuh ribu dua ratus rupiah perhari kerja efektif) yang dibayarkan perbulan. Selain itu buruh juga menerima upah lembur di mana perjam dibayar sebesar 21.069 yang akan terus meningkat perjamnya dan juga buruh harian lepas juga mendapatkan tunjangan kesehatan, fasilitas perumahan berserta sarana dan prasarana THR (Tunjangan Hari Raya) sebesar satu bulan gaji.

3. Tanggung jawab PT. Hanuraba Sawit Kencana terhadap pemenuhan hak normatif buruh harian lepas yang bersifat politis yaitu perusahaan tersebut mengizinkan terbentuknya serikat buruh bernama SPSI (Serikat Pekerja Seluruh Indonesia), artinya PT. Hanuraba Sawit Kencana tidak melarang buruh untuk bergabung dengan serikat buruh tersebut. Organisasi serikat buruh tersebut bernama SPSI (Serikat Pekerja Seluruh Indonesia), yang diketuai oleh Bapak Roso, namun serikat buruh tersebut vakum, hal ini disebabkan karena buruh harian lepas di PT. Hanuraba Sawit Kencana tidak memahami caranya berorganisasi serikat buruh dan bagaimana pelaksanaan-pelaksanaan kegiatan organisasi tersebut sehingga menyebabkan tidak adanya perwakilan antara buruh harian lepas dengan PT. Hanuraba Sawit Kencana saat terjadi masalah yang menyangkut hak-hak normatif buruh harian lepas.

4. Selanjutnya tanggung jawab PT. Hanuraba Sawit Kencana terhadap pemenuhan hak normatif buruh harian lepas yang bersifat medis yaitu PT. Hanuraba Sawit Kencana menyediakan fasilitas berupa POLIBUN (Poli Klinik Kebun) bagi karyawan-karyawannya. POLIBUN memiliki 2 bidan dan 1 perawat. PT. Hanuraba Sawit Kencana juga menanggung penuh pengobatan yang diakibatkan kecelakaan kerja yang terjadi selama bekerja, berangkat kerja dan pulang kerja. PT. Hanuraba Sawit Kencana juga menanggung penuh pengobatan buruh yang dirujuk ke rumah sakit di Palembang sampai buruh tersebut dinyatakan sehat.

5. Kemudian untuk tanggung jawab PT. Hanuraba Sawit Kencana terhadap pemenuhan hak normatif buruh harian lepas yang bersifat sosial, buruh harian lepas tidak mendapatkan cuti (baik buruh harian lepas pria maupun wanita), tetapi mereka bisa mengajukan izin tidak masuk kerja.

\section{DAFTAR PUSTAKA \\ Buku}

Ali,Zainuddin. 2014. Metode Penelitian Hukum.Jakarta: Sinar Grafika. Asyhadie,Zaeni. 2007.Hukum Kerja (Hukum Ketenagakerjaan Bidang Hubungan Kerja). Jakarta: Rajawali Pres.

R. Subekti. 2003. Pokok-Pokok Hukum Perdata cetakan ke-31. Jakarta: Intermasa.

Salim HS. 2014. Pengantar Hukum Perdata Tertulis (BW). Jakarta: Sinar Grafika.

Sugiarto,Umar Said. 2014.Pengantar Hukum Indonesia. Jakarta: Sinar Grafika.

Trijono,Rachmat. 2014.Pengantar Hukum Ketenagakerjaan. Depok Timur : Papas Sinar Sinanti

Purbacaraka. 2010. Perihal Kaedah Hukum. Bandung: Citra Aditya.

Wijayanti,Asri. 2016. Hukum Ketenagakerjaan Pasca Reformasi. Jakarta: SinarGrafika.

\section{Peraturan Perundang-undangan}

Undang-Undang No. 21 Tahun 2000 Tentang Serikat Pekerja/Buruh

Undang-Undang No. 13 Tahun 2003 tentang Ketenagakerjaan.

Keputusan Menteri Tenaga Kerja dan Transmigrasi No. 100 Tahun 2004 tentang Ketentuan Pelaksanaan Perjanjian Kerja Waktu Tertentu.

Keputusan Menteri Tenaga Kerja dan Transmigrasi No. 102 Tahun 2004 Tentang Waktu Kerja Lembur Dan Upah Kerja Lembur.

Keputusan Menteri Tenaga Kerja dan Transmigrasi No. 7 Tahun 2013 tentang Upah Minimum. 


\section{Sumber Lainnya}

http://staffnew.uny.ac.id/upload/132318574/penelitian/Menakar+kesejahteraan+buruh.pdf

https://www.abnp.co.id/news/question-answer-hak-normatif-buruh

Wawancara dengan pihak-pihak terkait di PT. Hanuraba Sawit Kencana 